\title{
BIODEGRADABILITY POTENTIAL OF TWO EXPERIMENTAL LANDFILLS IN BRAZIL
}

\author{
Rosana Filomena Vazoller'; Luciana Paulo Gomes ${ }^{2 *}$; Viviana Maria Zanta Baldochi ${ }^{1}$; \\ Denise Maria Fortes Villas-Bôas ${ }^{1}$; Rosileine Jabur Badra ${ }^{1}$; Jurandyr Povinelli ${ }^{1}$ \\ ${ }^{1}$ Escola de Engenharia de São Carlos, Departamento de Hidráulica e Saneamento, \\ Universidade de São Paulo, São Carlos, SP, Brasil. ${ }^{2}$ Universidade do Vale do Rio dos Sinos, Centro de Ciências Exatas e \\ Tecnológicas, São Leopoldo, RS, Brazil
}

Submitted: June 26, 2000; Returned to authors for corrections: August 29, 2000; Approved: May 25, 2001

\begin{abstract}
Solid wastes anaerobic biodegradability, methane production potential and microbiological composition of two experimental sanitary landfills in Brazil, running for one year, were evaluated. The two landfills showed a similar organic matter stabilization during the methane production phase, despite the high heterogeneity of the solid wastes. Both landfills presented the same level of methane (around $91.5 \mathrm{~L} \mathrm{CH}_{4} / \mathrm{kg}$ Volatile Total Solids) and organic acids, mainly acetic and butyric acids, in the leachate. Bacterial isolates belonged to genera Megasphaera, Selenomonas, Methanobacterium, Methanobrevibacter and Methanosarcina.
\end{abstract}

Key words: solid wastes, sanitary landfill, anaerobic biodegradability

\section{INTRODUCTION}

Use of sanitary landfills are a common method of disposing municipal solid wastes (MSW) (2). The availability of land, the low costs of construction and operation when compared to other systems, and the utilization of biogas as an alternative fuel make landfills one of the most attractive solutions for treatment of municipal solid wastes in Brazil. The biological anaerobic activity in sanitary landfills is comparable to what occurs in anaerobic environment (natural and bioreactors) (4). Despite the considerable knowledge on microbial activity in landfills in United States of America and Europe $(3,4,7,8,9,12,13,14,15)$, little information is available from Brazil.

The present work reports on biological transformations in two experimental landfills, constructed similarly to conventional landfills, with leachate drainage, biogas collectors and soil and grass covers. Refuse decomposition was studied without leachate recycling. The total amount of MSW in both landfills corresponded to eleven years of urban solid waste produced in a Brazilian city with 2,000 people with economical level similar to that of small cities in Europe.

\section{MATERIALS AND METHODS}

Two experimental landfills, with 3,380 and $2,500 \mathrm{~m}^{3}$ of capacity, were studied. They were provided with a waterproof system, comprised of Hypalon plastic and layers of sand and clay. Drainage systems for gases and leachate were built into the fills. The leachate was collected through a channel in the bottom of the landfills. The biogas was pumped out with drills through a PVC tube, involved by crushed stones to avoid obstructions, and installed in vertical position. The systems were filled with municipal solid wates (MSW) during 3 months and completely covered with plastic and a layer of compacted clay and turf.

\section{Municipal Solid Wastes (MSW) characterization}

Characterization of MSW was based on eight samples of garbage (100 kg each) obtained at four different areas of the city of São Carlos, São Paulo State, during summer and winter. The MSW were classified as food/gardening, paper, glass, metal, plastic, rag, wood/leather/rubber and others.

\footnotetext{
* Corresponding author. Mailing address: Universidade do Vale do Rio dos Sinos, Centro de Ciências Exatas e Tecnológicas, Caixa Postal 275, 93022-000, São Leopoldo, RS, Brasil.
} 


\section{Landfills samples}

Sampling was carried out using a mechanical auger at four depths: 2 to $2.5 \mathrm{~m}, 2.5$ to $3 \mathrm{~m}, 3$ to $3.5 \mathrm{~m}$ and 3.5 to $4 \mathrm{~m}$. $300 \mathrm{~g}$ of garbage free of plastic, glass and metals were used for analyses. Leachate was taken from well collectors connected to the channels in the bottom of the fills. Biogas was collected from the PVC tubes using a glass ampoule. For microbiological studies, samples were taken from the first depth, homogenized in plastic bags, and immediately transfered to flasks with reducing solution, under nitrogen atmosphere. Samples were taken over 400 days.

\section{Methane potential}

The anaerobic biodegradability of MSW was determined using the methane potential method described by Mounton et al. (12). Tests were carried out in batch conditions using serum bottles of $400 \mathrm{~mL}$. Municipal digesters sludge (100g) as source of anaerobic bacteria was mixed with MSW $(10 \mathrm{~g})$ from 2 to $2.5 \mathrm{~m}$, and incubated at $35^{\circ} \mathrm{C}$. Biogas production was monitored twice a day followed by methane determination. The age of sample was around one year.

\section{Chemical Oxygen Demand (COD), Volatile Total Solids (VTS), moisture and pH}

Analyses were done as described by APHA/AWWA/WPCF (1). Initial procedures for COD analyses were drying solid samples at $105^{\circ} \mathrm{C}$ during $24 \mathrm{~h}$, followed by maceration, acidification with sulphuric acid, addition of water up to $250 \mathrm{~mL}$ and filtration in GFC-Whatmann filters.

\section{Volatile organic acids and gases analyses}

Analyses of volatile organic acids and biogas were carried out by gas chromatography with a flame ionization detector. Semicapillary Q and Porapak Q columns and nitrogen and hydrogen as carrier gases were used, respectively, for acids and gases analyses. Total volatile organic acids were determined according to Ciola (6).

\section{Microbiological studies}

Strict anaerobe cultivation was done using the roll-tube method described by Hungate (10) and the liquid medium cultivation described by Miller and Wolin (11). Media for roll-tube enumeration and isolation of hydrolytic and fermentative bacteria were prepared according to Salinitro et al. (16). Identification of hydrolytic and fermentative bacteria in pure culture was based on Virginia Polytechnic Institute Manual (17). Methanogenic cultures were isolated in Basal-Carbonate-Yeast-Triptone media (18) supplemented with acetate, methanol, formate or hydrogen as energetic sources. Methanogenic bacteria identification was based on Bergey's Manual (5). Bacterial samples were taken during the last 200 days, both from landfilled solid wastes and leachate collected at experimental landfill flows. After the enumeration, the fermentative hydrolitic anaerobes were purified and isolates were maintained for further studies.

\section{RESULTS AND DISCUSSION}

The MSW composition was $56.7 \%$ food/gardening, $21.3 \%$ paper, $1.1 \%$ glass, $5.4 \%$ metal, $8.5 \%$ plastic, $3.4 \%$ rag, $2.3 \%$ wood/leather/rubber and $1.3 \%$ other materials. No differences were observed between seasons or areas. The high level of organic matter in MSW is characteristic of a tropical region with intensive agricultural and dairy activities close to an urban area, and of the economical people conditions and wastage of food. Organic matter is generally lower in big urban areas $(2,14,15)$. The amount of paper is probably related with the number of universities in the city, and the low percentage of glass was a result of domestic reutilization. The moisture level, $46.6 \%( \pm 5.8)$, is typical of high organic content and anaerobic process (14).

Fig. 1 illustrates the production of methane 90 days after closing the landfills. In both landfills, the production of methane was similar. During the studied period (300 days), methane values increased from 35 to $60 \%$, characterizing the methanogenic phase of the anaerobic decomposition (14). The methane potentials (Fig. 2) around this period were 97.8 and $85.1 \mathrm{~L} \mathrm{CH}_{4} / \mathrm{kg}$ VTS (mean values), for fills 1 and 2, respectively. From these results the extent of methane production by the landfills could be calculated. According to Attal et al. (2) the methane potential in landfills varies from 0.8 to $90 \mathrm{~L}$ biogas $/ \mathrm{kg}$ of degradable MSW. Pohland and Harper (14) indicated values of theoretical gas yields for biodegradable fractions as a range of 60 to $170 \mathrm{~L} / \mathrm{kg}$ of dry waste.

Figs. 3 to 6 show the VTS and COD values for solid waste samples at different depths. The variations between fills 1 and 2 at the same depth and time are probably related to the heterogeneity of MSW and the operation during the filling of the systems. Different sampling sites and analytical procedures

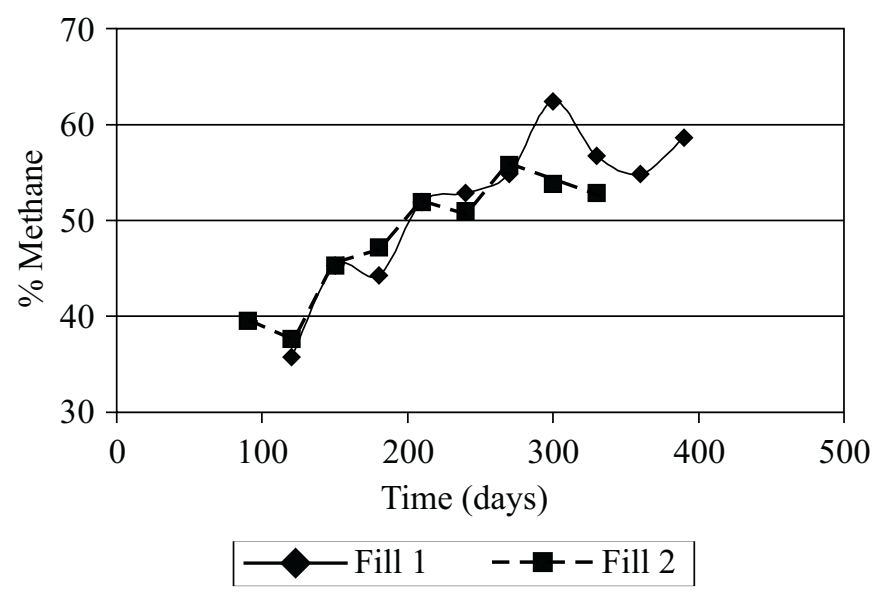

Figure 1. Methane gas production. 


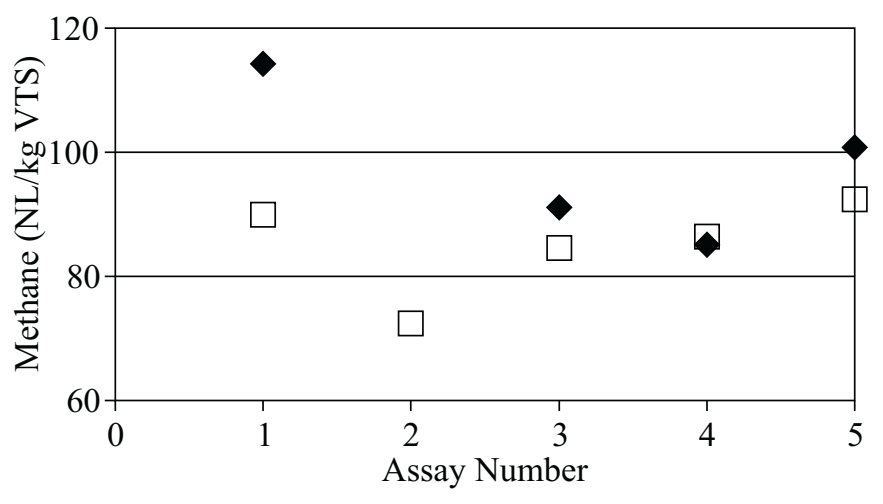

Fill $1 \quad \square \quad$ Fill 2

Figure 2. Methane potencial.

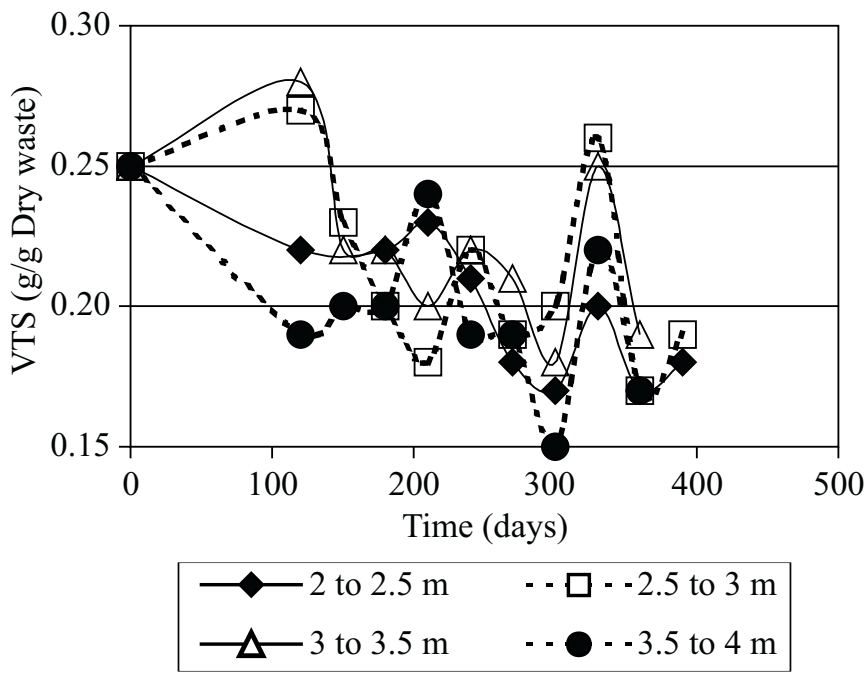

Figure 3. Volatile total solids measurements - Fill 1.

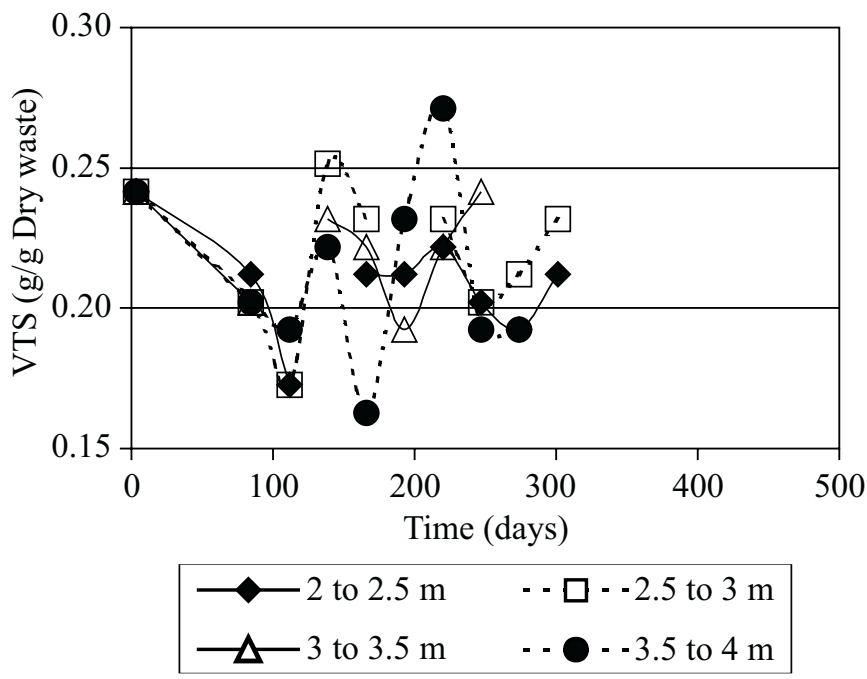

Figure 4. Volatile total solids measurements - Fill 2.
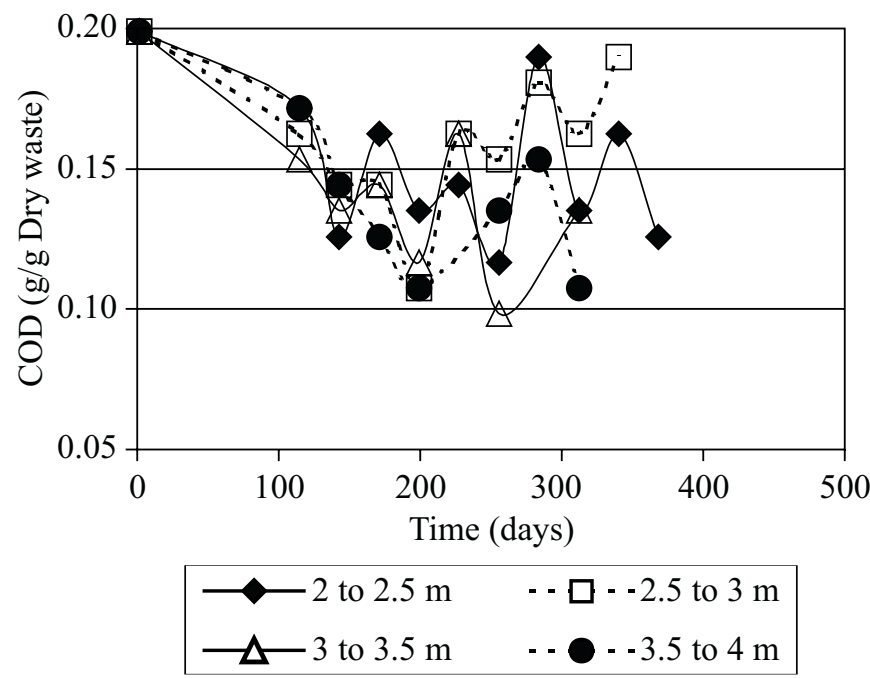

Figure 5. Chemical oxygen demand measurements - Fill 1.

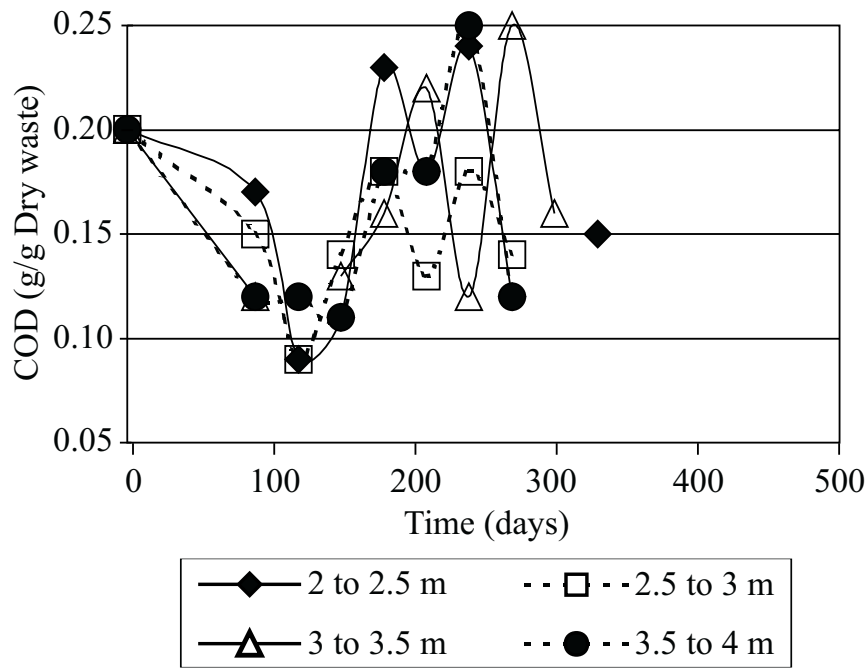

Figure 6. Chemical oxygen demand measurements - Fill 2.

could also be responsible for these differences. It should be noted that the initial values of COD and VTS were obtained from the fresh garbage sample. The first 100 days period was characterized by a decrease of VTS and COD. Mean values of COD removal, 38.5 and $37.5 \%$, and VTS reduction, 24.6 and $39.1 \%$, respectively for fills 1 and 2 , showed a slight degradation, considering the systems as a discrete cell of a landfill and without differences between the depths. During this period, the VTS contents of fill 1 at the intermediary depths increased and the sampling was the most probable reason for these differences. COD values after 100 days, and after more than one year, showed the same organic matter content in both landfills during the methane production phase, and the range of values, 0.10 to 0.20 $\mathrm{g} / \mathrm{g}$ of dry waste, was not very different from the initial values at 
any depth. The VTS contents of fill 1 were lower than fill 2 and no differences were observed between the depths. The results indicate that the methane phase was not stabilized after 400 days. It was possible to calculate the methane potential as VTS remaining as 0.20 to $0.25 \mathrm{~g} / \mathrm{g}$ of dry waste.

Figs. 7 and 8 show results of COD and VTS in the leachates. The values were similar in the first 150 days, decreased slowly up to 280 days, and decreased pronouncedly in both parameters at 300 days.

Solid organic matter breakdown resulted in products with initial values of COD around $40 \mathrm{~g} / \mathrm{L}$ and VTS content around 25 $\mathrm{g} / \mathrm{L}$, for leachates 1 and 2 . Volatile organic acid production and $\mathrm{pH}$ values (Figs. 9 to 12 ) show the occurrence of hydrolysis inside the fills. The amount of total volatile organic acids (Fig. 12), and particularly the amount of individual volatile acids, indicates hydrolytic and acetogenic bacterial activities, with acetic, butyric and propionic acids as the main fermentation products, at $\mathrm{pH} 5.5$ to 6.0. The count of non-methanogenic bacteria in the leachate was $7.5( \pm 0.14) \log$ CFU (Colonies

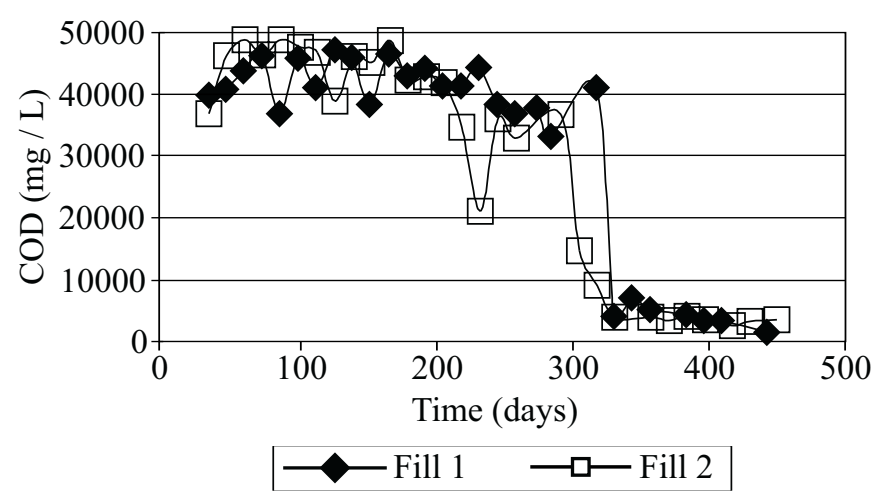

Figure 7. Chemical oxygen demand measurements from leachate.

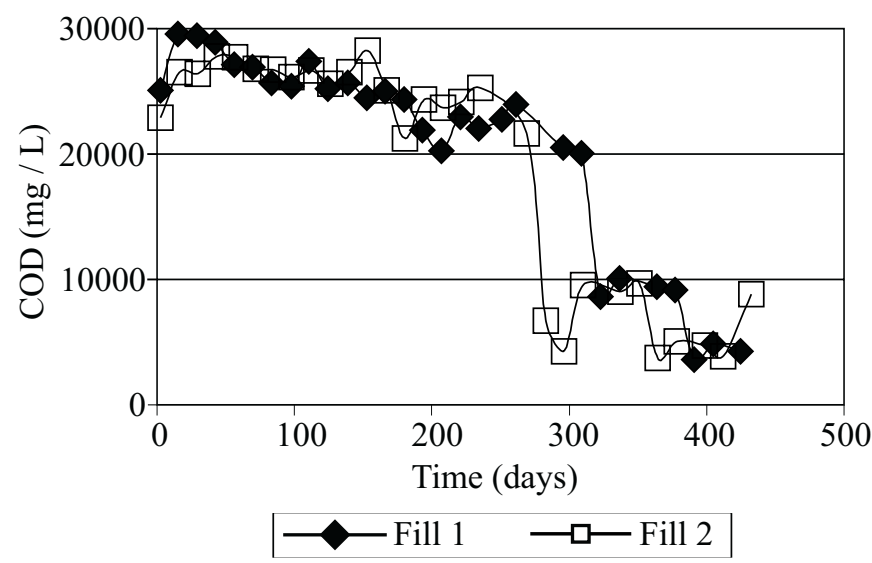

Figure 8. Volatile total solids measurements from leachate.
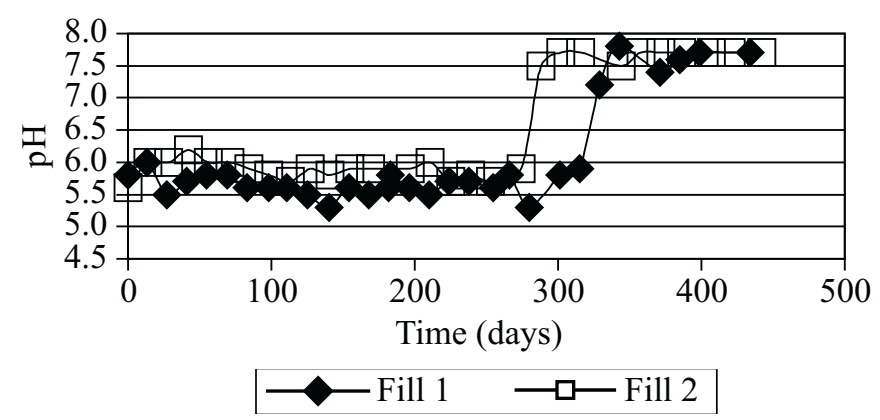

Figure 9. pH measurements from leachate.

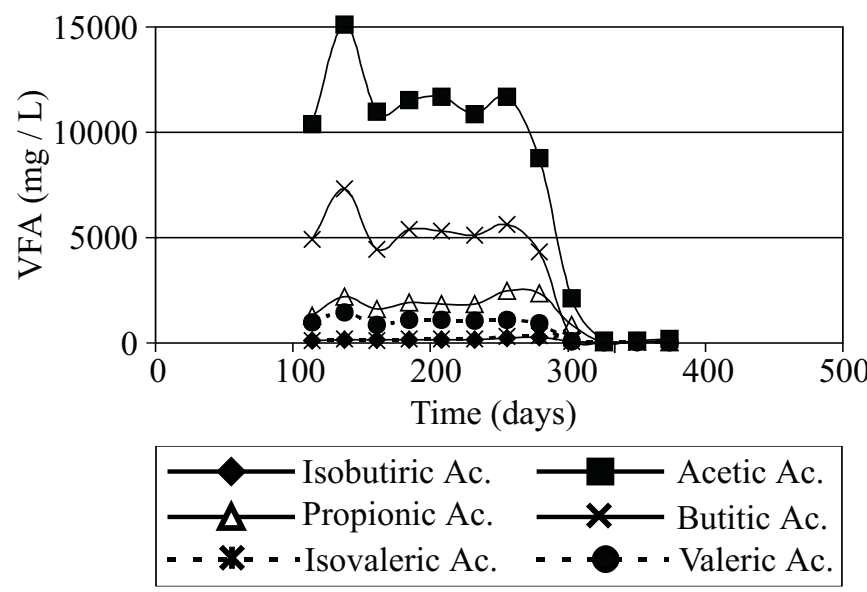

Figure 10. Volatile fatty acids - Fill 1.

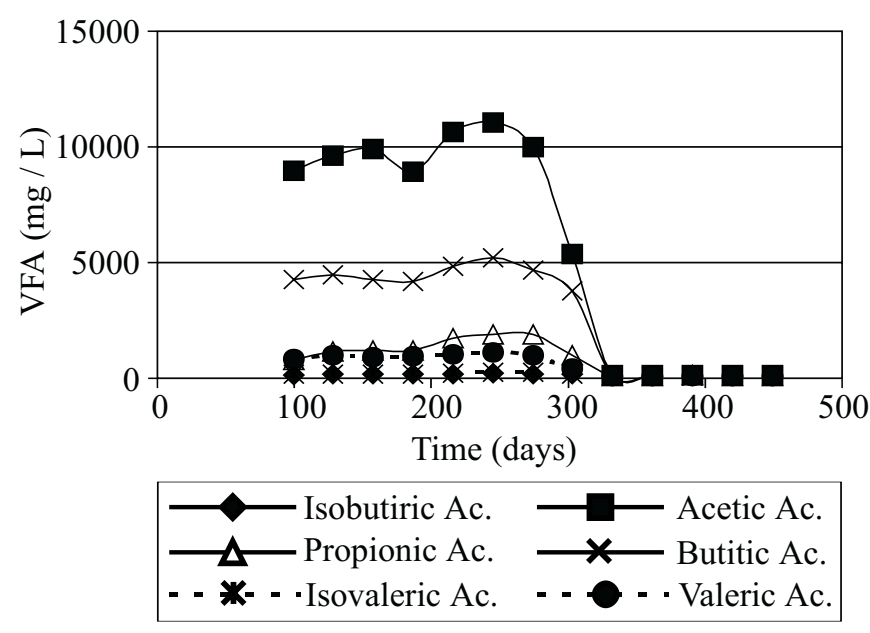

Figure 11. Volatile fatty acids - Fill 2.

Forming Unids $/ \mathrm{mL}$. During this time the $\mathrm{pH}$ and methanogenic activity also increased (Fig. 1). pH of leachate increased to 7.8. After 300 days, the pronounced decrease in all leachate parameters studied pointed to stabilization of organic matter 
degradation, and the remaining COD and VTS of solid wastes (Figs. 3 to 6) confirmed that this period was still in an accelerated methane production phase. The results are consistent with other refuse decomposition experiments where the solids remaining at this methane phase are almost 70-75\% (4).

Care was taken during hydrolytic-fermentative bacterial enumeration (Table 1), since the microorganisms in the refuse may be attached to fibrous materials like cellulose or inert solids. A range of 5.5 to $8.0 \log \mathrm{CFU} / \mathrm{g}$ dry waste was obtained at different points of the landfills. Two proteolytic bacteria isolated were Megasphaera sp and Selenomonas sp. Methanogenic bacteria enriched from solid waste belonged to the genera Methanobacterium, Methanobrevibacter and Methanosarcina. Methanogenic enrichments were performed using solid wastes from both landfills at the methane phase. The Methanosarcina species had morphological characteristics similar to the species $M$. acetivorans, whose life cycle includes cyst formation.

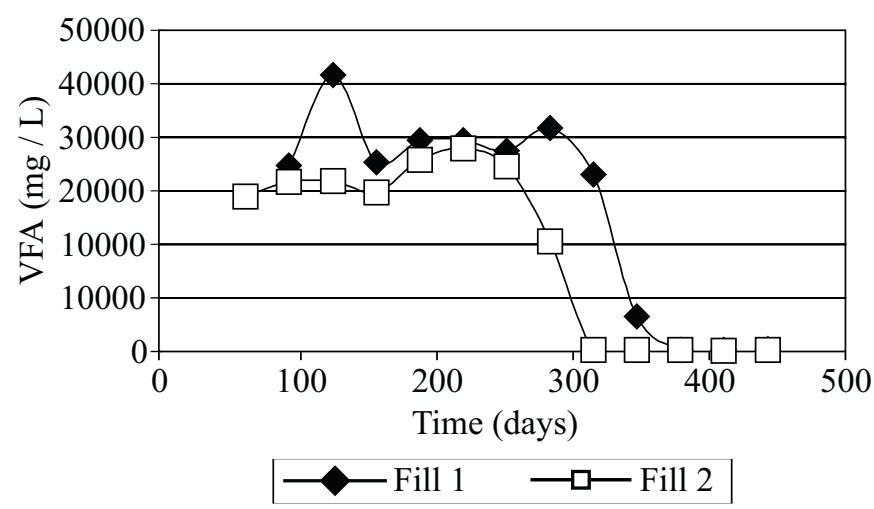

Figure 12. Total volatile fatty acids.

Table 1. Counts of hydrolytic fermentative anaerobic bacteria in fills 1 and 2 at 2 to $2.5 \mathrm{~m}$ depth.

\begin{tabular}{cccc}
\hline \multicolumn{2}{c}{ Fill 1 } & \multicolumn{2}{c}{ Fill 2 } \\
\hline $\begin{array}{c}\text { Degradation } \\
\text { time (days) }\end{array}$ & $\begin{array}{c}\text { log CFU / g } \\
\text { dry waste }\end{array}$ & $\begin{array}{c}\text { Degradation } \\
\text { time (days) }\end{array}$ & $\begin{array}{c}\text { log CFU / g } \\
\text { dry waste }\end{array}$ \\
\hline 247 & $5.74( \pm 0.4)$ & 224 & $5.56( \pm 0.1)$ \\
261 & $5.94( \pm 0.2)$ & 238 & $6.09( \pm 0.3)$ \\
275 & $7.93( \pm 0.3)$ & 252 & $7.62( \pm 0.5)$ \\
289 & $6.49( \pm 0.9)$ & 266 & $6.32( \pm 0.4)$ \\
303 & $5.87( \pm 0.4)$ & 280 & $6.49( \pm 0.8)$ \\
317 & $5.17( \pm 0.2)$ & 294 & $8.22( \pm 0.04)$ \\
360 & $6.31( \pm 0.1)$ & 337 & $5.64( \pm 0.2)$ \\
367 & $6.51( \pm 0.3)$ & 344 & $6.69( \pm 1.0)$ \\
373 & $7.40( \pm 1.0)$ & 350 & $6.12( \pm 0.2)$ \\
394 & $7.90( \pm 0.5)$ & 371 & $7.72( \pm 0.5)$ \\
408 & $5.60( \pm 0.3)$ & 385 & $5.59( \pm 0.5)$ \\
\hline
\end{tabular}

\section{CONCLUSIONS}

The MSW contained 50 to $70 \%$ of organic matter, and its anaerobic degradation was confirmed by the formation of products like methane and leachate. After one year, the experimental landfills represented scale-up systems, running in the methane production phase. Despite the MSW heterogeneity, the results showed similar biological activities for fills 1 and 2 . Methane potential values indicated further gas production by the remaining MSW. This method could be very useful to predict the capacity of biogas production in landfills.

\section{ACKNOWLEDGMENTS}

The authors acknowledge to Conselho Nacional de Desenvolvimento Científico e Tecnológico - CNPq and FINEP for the grants received during the research. Special thanks to Prof. Dr. J. Pohland for the correction of English.

\section{RESUMO}

\section{Potencial de biodegrabilidade de dois aterros sanitários experimentais no Brasil}

Durante um ano foi realizado o monitoramento da biodegradabilidade anaeróbia de resíduos sólidos, do potencial de geração de metano e da composição microbiológica de dois aterros sanitários experimentais. Observou-se que, apesar da grande heterogeneidade dos resíduos sólidos, os resultados em termos de estabilização de matéria orgânica durante a fase de produção de metano foram similares para os dois aterros. Ambos os sistemas apresentaram as mesmas faixas de produção de metano (91.5 $\mathrm{L} \mathrm{CH}_{4} / \mathrm{kg} \mathrm{STV} \mathrm{-} \mathrm{sólidos} \mathrm{totais} \mathrm{voláteis)} \mathrm{e} \mathrm{de} \mathrm{ácidos}$ orgânicos, principalmente ácidos acético e butírico. Isolou-se ainda, culturas bacterianas dos gêneros Megasphaera, Selenomonas, Methanobacterium, Methanobrevibacter and Methanosarcina.

Palavras-chave: resíduos sólidos urbanos, aterros sanitário, bidegradação anaeróbia

\section{REFERENCES}

1. APHA/AWWA/WPCF. Standard methods for the examination of water and wasterwater, $19^{\mathrm{a}}$ ed, 1995.

2. Attal, A.; Akunna, J.; Camacho, P.; Salmon, P.; Paris, I. Anaerobic degradation of municipal wastes in landfill. In: $6^{\circ}$ International Symposium of Anaerobic Digestion In: $6^{\circ}$ International Symposium of Anaerobic Digestion, São Paulo, Brazil, 1991, pp.229-238.

3. Barlaz, M.A.; Schaefer, D.M.; Ham, R.K.. Effects of prechiling and sequential washing or enumeration of microorganisms from refuse. Appl. Environ. Microbiol., 55:50-54, 1989a.

4. Barlaz, M.A.; Schaefer, D.M.; Ham, R.K. Bacterial populations development and chemical characteristics of refuse decomposition in a simulated sanitary landfill. Appl. Environ. Microbiol., 55:55-56, 1989b. 
5. Bergey's Manual of Systematic Bacteriology. Vol.3. N.R. Krieg Publisher, 1988.

6. Ciola, R. Fundamentos da cromatografia a gás - Instrumentos científicos CG Ltda.São Paulo: Ed. Edgard Blücher Ltda. 1985.

7. Fielding, E.; Archer, D.B.; Macario, E.C.; Macario, A.J.L. Isolation and characterization of methanogenic bacteria from landfills. Appl. Environ. Microbiol., 54:835-836, 1988.

8. Filip, Z.; Kuster, E. Microbial and the turnover of organic matter in a municipal refuse disposed of in a landfill. Eu. J. Microbiol. Biotechnol., 7:371-379, 1979

9. Filip, Z.; Smed-Hildmann, R. Microbial activity in sanitary landfills a possible source of the humic substances in groundwater ? Wat. Sci. Tech., 20(3):55-59, 1988.

10. Hungater, R.E. A roll tube method for cultivation of strict anaerobes. In: Norris, J.R.; Ribbons, D.W. Methods in Microbiology, New York Academic Press, v.2, 1969, p.117-132.

11. Miller, T.L.; Wolin, M.J. A serum bottle modification of the Hungate Technique for cultivating obligate anaerobes. Appl. Microbiol., 27:985987, 1974.
12. Mounton, C.; Beckelynck, J.; Albagnac, G.; Dubourguier, H.C. Production et recuperation de biogaz produit par les ordures menageres enfouies em decharge. T.S.M.L'Eau, 80(9):391-404, 1985.

13. Nozhevnikova, A.N.; Lebeden,V.S.; Lifshitz, A.L.B.; Zavarzin, G.A. $6^{\circ}$ International Symposium of Anaerobic Digestion, São Paulo, Brazil, 1991, p.239-48.

14. Pohland, J.G.; Harper, S.R. Critical review and summary of leachate and gas production from landfills. Atlanta, Georgia Inst. of Technol., School of Civil Engineering, 1985, 165p.

15. Rees, J.F. The fate of carbon compounds in the landfill disposal of organic matter. J. Chem. Tech. Biotechnol., 30:161-175, 1980.

16. Salanitro, J.P.; Fairchilds, I.G.; Zgonicki, Y.D. Isolation culture characteristics and identification of anaerobic bacteria from the chicken cecum. Appl. Microbiol., 27:678-687, 1974.

17. Virginia Polytechnic Institute - Anaerobe Laboratory Manual. L.V. Holdeman \& W.E.C. Moore Eds., Blacksburg, Virginia, 1975, 132p.

18. Touzel, J.P.; Albagnac, G. Isolation and characterization of Methanococcus mazei strain MC3. FEMS Microbiol. Letters, 16:241$245,1983$. 